\title{
Effects of CigaretteSmoke on the Meckel's Cartilage of Rat Fetus: Morphologic, Morphometric and Stereologic Study
}

\author{
Daniela Atili BRANDINI ${ }^{1}$ \\ Miguel Angel SALA ${ }^{2}$ \\ Ruberval Armando LOPES ${ }^{2}$ \\ Marisa SEMPRINI ${ }^{2}$ \\ Mary Garcia DuarteCONTRERA ${ }^{3}$ \\ ${ }^{1}$ Department of Surgery and Integrated Clinics, Faculty of Dentistry of Araçatuba, \\ São Paulo State University (UNESP), Araçatuba, SP, Brazil \\ ${ }^{2}$ Department of Morphology, Stomatology and Physiology, Faculty of Dentistry of Ribeirão Preto, \\ University of São Paulo (USP), Ribeirão Preto, SP, Brazil \\ ${ }^{3}$ University of Franca (UNIFRAN), Franca, SP, Brazil
}

\begin{abstract}
The purpose of this study was to investigate the effects of cigarette smoke on the development of the embryo mandible (Meckel's) cartilage in rat fetuses. When inhaled by female Wistar rats between the 9 th and the 12 th day of pregnancy, cigarette smoke ( 5 cigarettes a day) caused intrauterine growth retardation, providing smaller fetuses and placentas. In fetuses from the experimental group, the histopathologic examination revealed a poorly developed Meckel's cartilage with smaller chondroblasts showing a scanty cytoplasm with spherical and paler central nuclei, as well as more abundant cartilage matrix. Morphometric analysis revealed that Meckel's cartilage lacunae were smaller in the fetuses from the experimental group, although not showing any remarkable alteration in shape. The results suggested that inhalation of cigarette smoke by pregnant rats during the organogenic period induced growth retardation and delayed cellular differentiation in rat fetal Meckel's cartilage.
\end{abstract}

Key Words: Meckel's cartilage, cigarette smoke, morphometry, rat fetus.

\section{INTRODUCTION}

Cigarette smoking constitutes a crucial problem of public health and its deleterious effects on human health are well documented. The toxic compounds of cigarettes reach the organism by the smoking habit (active smoking) or, involuntarily, by the contact with an environment polluted with tobacco products (passive smoking). In the second category are included the fetuses from mothers who smoke during pregnancy.

Among the almost 4,700 substances present in cigarette smoke, the most known by their toxic effects are carbon monoxide, ammonia, formaldehyde, acetaldehyde, acrolein, tar and nicotine. Moreover, tar has carcinogenic particles such as arsenic, polonium, DDT, nickel, benzopyrene, cadmium and dibenzacridine.

An increasing incidence of smoking women in the general population has been reported, and approximately $35 \%$ of these women continue to smoke during pregnancy as if cigarettes would not implicate in risk for the fetus. However, the act of smoking one single cigarette causes an increase of fetal heartbeat and an acute decrease of the uteroplacental blood flow, lasting for approximately $15 \mathrm{~min}$ after finishing smoking.

Furthermore, cigarettes are responsible for a high percentage of neonatal and perinatal pathologies, premature births, respiratory distress and sudden infant death syndrome. The effect of cigarette smoke is independent from any other known factor that exerts its influence on the newborn, such as maternal age, parity,

Correspondence: Prof. Dr. Miguel A. Sala, Departamento de Morfologia, Estomatologia e Fisiologia, Laboratório de Patologia, Faculdade de Odontologia de Ribeirão Preto, USP, 14040-904 Ribeirão Preto, SP, Brasil. Fax: +55-16-633-0999. e-mail: masdmatt@ forp.usp.br 
race, preconceptional weight, weight gain during pregnancy, marital and socioeconomic status, height and gestational age (1).

The existence of an increased frequency of malformations among fetuses from smoking mothers is still controversial (2). After the administration of an aqueous extract of tobacco to pregnant rats, some malformations were detected, i.e., appearance of a third ventricle, unilateral hypoplastic testicle, distended bladder with thinned walls, thickened heart ventricular septum and trisepted ventricles of thinned walls (3). Thus, studies that corroborate the harmful effects of cigarette smoke on fetuses may contribute to persuade women to change their habits or, at least, stop smoking during pregnancy (4).

In the embryonic period, the germ layers give origin to specialized tissues. Mesoderm gives origin to all the supporting tissues (connective, cartilaginous and osseous tissues), muscular tissues, blood cells and marrow, lymphatic organs, endothelium lining blood and lymphatic vessels, mesothelium and adrenal cortex (5).

Mandibular processes contribute to skull conformation. The mesenchymal core of each mandibular process transforms into a cartilaginous bar called Meckel's cartilage. The Meckel's cartilage is a cylindrical stick of hyaline cartilage, constituted by two halves (right and left) that form the rostral process when joining in the area of the median line. The function of Meckel's cartilage is to guide the development of the jaw. This cartilage is composed of a matrix of apparently homogeneous ground substance and connective tissue fibers and cellular elements, the chondrocytes, which reside in small spaces in the matrix, called lacunae or chondroplasts. A fibrous membrane, the perichondrium, covers the outer surface of the cartilage.

The development of the hyaline cartilage begins with the proliferation and differentiation of the mesenchymal cells into chondroblasts, which are responsible for matrix production. The differentiation of chondroblasts extends from the center to the periphery, in such a way that the central cells show the characteristics of mature cartilage cells or chondrocytes, whereas the peripheral cells are still typical chondroblasts. The superficial mesenchyme originates the perichondrium. Cartilage grows in two ways: the first, called interstitial growth, occurs by mitotic division and the second, known as appositional growth, occurs by apposition of the fibroblasts pertaining to the chondrogenic layer of the perichondrium. These fibroblasts proliferate and differentiate into chondroblasts.

Meckel's cartilage maintains its structural characteristics for a short period of time and, along development, this cartilage is almost totally reabsorbed to form the mandibular bone (6).

The purpose of this study was to investigate the possible morphologic and morphometric alterations of the Meckel's cartilage induced by maternal exposure to cigarette smoke during the organogenic period.

\section{MATERIAL AND METHODS}

Nulliparous albino Wistar rats (Rattus norvegicus), weighing between 200 and $250 \mathrm{~g}$, were used. The rats were placed with fertile males overnight and the following morning was considered the first day of pregnancy, whenever sperm was present in the vaginal smears.

Pregnant rats were divided into two groups of 5 animals each: experimental (smoking group) and control (non-smoking group). The animals of the smoking group were exposed to the smoke of five cigarettes per day, from the 9 th to the 12 th day of pregnancy, while kept inside a special acrylic chamber. The chamber had an entrance hole, where the cigarette was placed to burn, and an exit hole, where a suction bomb was connected to aspirate the smoke inside the chamber. The animals remained inside the chamber until the cigarettes were consumed. The control group was submitted to the same experimental conditions of the experimental group, but without exposure to smoke. The female rats not exposed to cigarette smoke were housed in individual cages in an environmentally controlled room and fed commercial ration and water ad libitum.

On the 19th day of pregnancy, the rats were sacrificed by inhalation of anesthetic ether and the fetuses and placentas were removed through a wide abdominal incision and immediately fixed in a solution of $85 \mathrm{~mL} 80 \%$ alcohol, $10 \mathrm{~mL}$ formalin and $5 \mathrm{~mL}$ glacial acetic acid. After $24 \mathrm{~h}$ of fixation, the fetuses and placenta were blotted dry and weighed in a precision balance.

Five fetuses chosen at random from the smoking group and five from the control group were used in this study. The heads, separated from the bodies, were cut in half along the sagittal plane, embedded in paraffin, cut into serial $6 \mu \mathrm{m}$-thick sections and stained with hema- 
toxylin and eosin.

For the morphometric analysis, histologic sections were observed with a final magnification of X1000 and 50 lacunae from the Meckel's cartilage of each animal were drawn on paper. In the obtained drawings, the longest and shortest axes of lacunae were measured with the aid of a millimetric scale. By knowing both diameters, the following morphometric parameters were assessed: mean geometric diameter, greatest diameter to smallest diameter ratio, perimeter, area, surface, volume, surface to volume ratio, area to volume ratio, shape factor, contour index and eccentricity (7).

Stereologic analysis was performed on Meckel's cartilage drawings, obtained by projection on a 100point test grid (8) with a final magnification of X1000. The stereologic assay was used to estimate the volume densities of lacunae and cartilaginous ground substance and the numeric density of lacunae.

Statistical analysis of the results was performed using Mann-Whitney's nonparametric test (9).

\section{RESULTS}

Fetal body weights were significantly lower in the group submitted to inhalation of cigarette smoke $(2.90 \pm 0.06 \mathrm{~g})$ than in the control specimens $(4.25 \pm$ $0.25 \mathrm{~g})(\mathrm{p}<0.01)$.

The group of smoking pregnant rats showed significantly lower placental weights $(301.3 \pm 36.7 \mathrm{mg})$ than the control group $(510.7$ $\pm 83.4 \mathrm{mg})(\mathrm{p}<0.01)$. In addition, placental volumes were significantly lower in the smoking group than in the control group $(0.25 \pm$ $0.03 \mathrm{~mL}$ and $0.44 \pm 0.07 \mathrm{~mL}$, respectively) $(\mathrm{p}<0.01)$. In contrast, placental index (placental weight to fetal weight ratio) was significantly higher in the group of fetuses from rats submitted to the action of cigarette smoke $(0.335 \pm 0.019)$ than in the fetuses from the control rats $(0.119 \pm 0.014)(\mathrm{p}<0.01)$.

Histopathologic examination revealed that Meckel's cartilage in control fetuses was constituted by a hyaline cartilage with homogeneous ground substance. Chondrocytes were seen residing in small lacunae and often appeared shrunken. These cells generally have a single nucleus, but some binuclear cells may be observed. Chondrocyte nucleus was of modgroups. erate size, disposed in a central or slightly eccentric position. The nucleus appeared spherical and clear, with scanty chromatin, showing a central nucleolus, not always evident. The lacunae were large, rounded and of homogeneous size. They sometimes became polygonal by the compression of the neighboring lacunae. In the peripheral region of the cartilage, lacunae were rather small and flattened with their longest axis parallel to the perichondrium. The cartilage ground substance became homogeneous in the periphery, but in the cartilage's central region, it was scarce, constituting true thin partitions among the adjacent lacunae. In some specimens, the existence of zones of hypertrophy and erosion was evident.

Meckel's chondrocytes appeared irregularly disposed and shrunken into the lacunae, and were smaller in the fetuses from the test animals than in those from the control group. They showed central or slightly eccentric, relatively large and clear nuclei, with an ample central nucleolus, not always visible. Lacunae appeared more numerous in the treated animals than in the control ones, although they were smaller and of variable sizes. The cartilaginous ground substance was more abundant in the treated specimens than in the control animals.

Morphometric analysis of the Meckel's cartilage

Table 1. Mean values for the morphometric parameters of Meckel's cartilage lacunae in fetuses from the control (non-smoking) and experimental (smoking)

\begin{tabular}{lrccc}
\hline Parameter & Control & Experimental & Ucalc & $\mathrm{p}$ \\
\hline Greatest diameter $(\mu \mathrm{m})$ & 29.06 & 14.98 & 0 & $<0.01$ \\
Smallest diameter $(\mu \mathrm{m})$ & 21.48 & 11.00 & 0 & $<0.01$ \\
Mean diameter $(\mu \mathrm{m})$ & 24.89 & 12.79 & 0 & $<0.01$ \\
D/d & 1.33 & 1.39 & 4.5 & $\mathrm{~ns}$ \\
Perimeter $(\mu \mathrm{m})$ & 79.99 & 41.13 & 0 & $<0.01$ \\
Area $\left(\mu \mathrm{m}^{2}\right)$ & 495.52 & 129.69 & 0 & $<0.01$ \\
Surface $\left(\mu \mathrm{m}^{2}\right)$ & 1982.08 & 518.76 & 0 & $<0.01$ \\
Surface/volume ratio $\left(\mu \mathrm{m}^{-1}\right)$ & 0.23 & 0.46 & 0 & $<0.01$ \\
Volume $\left(\mu \mathrm{m}^{3}\right)$ & 8533.21 & 1126.89 & 0 & $<0.01$ \\
Area/volume ratio $\left(\mu \mathrm{m}^{-1}\right)$ & 0.06 & 0.117 & 0 & $<0.01$ \\
Eccentricity & 0.59 & 0.65 & 4.5 & $\mathrm{~ns}$ \\
Shape factor & 0.96 & 0.96 & 5 & $\mathrm{~ns}$ \\
Contour index & 3.61 & 3.63 & 7 & $\mathrm{~ns}$ \\
\hline
\end{tabular}

Mann-Whitney test Ucalc $=$ U calculated ns $=$ nonsignificant . $\mathrm{D} / \mathrm{d}=$ Greatest diameter to smallest diameter ratio. 
Table 2. Mean values for the stereologic parameters of Meckel's cartilage in fetuses from control (non-smoking) and experimental (smoking) groups.

\begin{tabular}{lcccc}
\hline Parameter & Control & Experimental & Ucalc & $\mathrm{p}|\mathrm{U}|$ \\
\hline $\begin{array}{l}\text { Lacunae } \\
\quad \text { Relative volume }(\%)\end{array}$ & 61.1 & 43.1 & 0 & $<0.01$ \\
$\quad \begin{array}{l}\text { Numeric density }\left(\mathrm{n} / \mathrm{mm}^{3}\right) \\
\text { Cartilage matrix }\end{array}$ & 71.602 & 418.851 & 0 & $<0.01$ \\
$\quad$ Relative volume $(\%)$ & 38.9 & 56.9 & 0 & $<0.01$ \\
\hline
\end{tabular}

Mann-Whitney test: $\mathrm{Ucalc}=\mathrm{U}$ calculated $; \mathrm{p}|\mathrm{U}|=$ probability of $\mathrm{U}$.

showed that diameter, volume, area, perimeter and surface were smaller in fetuses from the experimental group, whereas the volume to area ratio and the surface to volume ratio of the lacunae were significantly increased in the smoking group. No alteration was observed in the shape of Meckel's cartilage lacunae from fetuses of animals exposed to the action of cigarette smoke during pregnancy (Table 1).

The stereologic assay revealed that fetuses from the smoking group presented significantly smaller lacunae volume density and significantly larger volume density of cartilaginous ground substance and numeric lacunae density (Table 2).

\section{DISCUSSION}

The findings of this study showed that fetuses from the smoking rats group were lighter than those from the control group. These results are consistent with the data found in the literature $(3,10-16)$.

Paulson et al. (3) demonstrated a direct relationship between nicotine dose and decrease of the fetal weight, number of resorptions and malformations, embryotoxicity and intrauterine growth retardation. It is now accepted that an important causing factor of intrauterine growth retardation in smoking mother's conceptuses is fetal hypoxia and/or ischemia due to reduction of the uteroplacental blood flow by both carbon monoxide and nicotine of the cigarette (4).

The present investigation revealed that cigarette smoke might provoke alterations at cellular level, even in a passive absorption. Accordingly, Haworth and Ford (10) reported that the exposure of pregnant rats to cigarette smoke causes delayed cellular growth in the fetus.

The stereologic analysis showed significant dif- ferences between treated and control animals. The mean value of lacunae volume density was significantly smaller in fetuses of the group treated with cigarette smoke. However, there are few investigations dedicated to study the action of tobacco components on cellular development, and thus discussion of this subject is limited.

It is known that any center of endochondral or intramembranous mandibular ossification may be teratogenically induced, which may probably originate a congenital mandibular anomaly. Because of the participation of Meckel's cartilage in the mandibular ossification, any alteration in its development may result in the absence, deformity or reduction of the jaw size. An effective dose of teratogen before the 13th day after insemination probably inhibits the Meckel's cartilage differentiation (17).

The mesenchymal core of the mandibular process becomes a cartilaginous bar, the Meckel's cartilage, which extends dorsally into the tympanic cavity of the ear, where it is encased by the future temporal bone. Despite the presence of this ancestral jaw material, this structure does not convert into the definitive mandible. Instead, membranous bone is substituted for strengthening the primitive mandible and providing support for the teeth. This replacing bone develops ventrally in the body of the future lower jaw and encloses both the Meckel's cartilage and the inferior alveolar nerve. (18). The portion of Meckel's cartilage invested by bone disappears and does not contribute to the formation of the permanent jaw, except at the tip (chin). The mandible itself represents the fusion of the two substitute halves, each with a single center.

In the present study, the Meckel's cartilage and the mandibular osseous tissue in specimens of the experimental group appeared to be scantly differentiated and constituted by small lacunae and abundant, poorly calcified ground substance. On the other hand, in the control group, the Meckel's cartilage showed a portion of calcified matrix among the expanded lacunae, whereas in other specimens apparent erosion of the cartilage was observed.

Intense cellular proliferation and differentiation have been observed in the Meckel's cartilage from mice with normal development up to the 13th day of pregnancy. Nineteen-day old embryos showed calcification of the perichondral collar and extensive calcification of the Meckel's cartilaginous matrix. On the 20th day, 
ossification zones were observed, especially zones of hypertrophied cartilage, calcification and erosion (17). In this study, the stereologic analysis of Meckel's cartilage showed a smaller volume density of lacunae and greater volume density of ground substance in the test animals, which are typical characteristics of the Meckel's cartilage in the initial period of growth. This fact denotes the tissue immaturity in the test animals. Increased numeric density of lacunae was observed in the experimental group, indicating that Meckel's cartilage cells did not grow and were not reabsorbed in the same manner as observed within the normal development of the cartilage. In the treated group, Meckel's cartilage lacunae showed smaller diameter, volume, area, perimeter and surface when compared to the control group, leading us to conclude that the experimental group had a larger number of cells $/ \mathrm{mm}^{3}$, although those cells were smaller.

Based on the results of this study, it may be concluded that cigarette smoke had harmful effects on the fetuses and placentas, because both fetal and placental weights were reduced in the animals of the experimental group. Cigarette smoke also had a negative influence on cell proliferation and differentiation of the fetal Meckel's cartilage. The lacunae of the Meckel's cartilage from test animals were smaller and showed decreased volume density when compared to those of control animals.

\section{RESUMO}

O objetivo deste estudo foi investigar os efeitos da fumaça de cigarros sobre o desenvolvimento da cartilagem mandibular (cartilagem de Meckel) do embrião de rato. Quando inalado por ratas Wistar, entre o $9^{0}$ e o $12^{\circ}$ dia de prenhez, a fumaça de cigarros (5/dia) provocou retardo do crescimento intrauterino, com fetos e placentas menores. Nos fetos do grupo experimental, o exame histopatológico revelou uma cartilagem de Meckel pouco desenvolvida, com condroblastos menores apresentando citoplasma escaso com núcleos mais pálidos, esféricos e centrais, assim como uma matrix cartilaginosa mais abundante. A análise morfométrica revelou que as lacunas da cartilagem de Meckel eram menores nos fetos do grupo experimental, não apresentando alteração significativa de sua forma. Os resultados sugeriram que a fumaça de cigarros inalada pelas ratas prenhes durante o período de organogênese induziu retardo tanto do crescimento quanto da diferenciação celular na cartilagem de Meckel dos fetos.

\section{REFERENCES}

1. Rocha JES, Matheus M, Sala MA. Effect of cigarette smoke on human placenta: a case-control study. Int J Gynecol Obstet 1998;62:37-242.

2. Johnston C. Cigarette smoking and the outcome of human pregnancies: a status report on the consequences. Clin Toxicol 1981;18:189-209.

3. Paulson R, Shanfeld J, Sachs L, Prince T, Paulson J. Effect of smokeless tobacco on the development of the CD-1 mouse fetus. Teratology 1989;40:483-494.

4. Donnenfeld A, Pulkkinen A, Palomaki GE, Knight GJ, Haddow JE. Simultaneous fetal and maternal cotinine levels in pregnant women smokers. Amer J Obstet Gynecol 1993;167:781-782.

5. Sadler TW, Langman J. Langman's Medical Embryology. 7th ed. Philadelphia: Lippincott, Williams \& Wilkins, 1995.

6. Burkitt HG, Young B, Heath JW. Wheatear's Functional Histology. 3rd ed. Philadelphia: Churchill Livingstone, 1993.

7. Sala MA, Komesu MC, Lopes RA, Maia Campos G. Karyometric study of basal cell carcinoma. Braz Dent J 1994;5:11-14.

8. Merz WA. Streckenmessung an gerichteten Strukturen im Mikroskop und Anwendung zur Bestimmung von Oberflächen volumen Relationen im Knochengewebe. Mikroskopie 1968;22:132-142.

9. Conover WJ. Practical Nonparametric Statistics. 3rd ed. New York: John Wiley \& Sons, 1999.

10. Haworth JC, Ford JD. Comparison of the effect of maternal undernutrition and exposure to cigarette smoke on the cellular growth of the rat fetus. Amer J Obstet Gynecol 1972;112:653656.

11. Persson P, Grennert L, Gennser G. The study of smoking and pregnancy with special reference to fetal growth. Acta Obstet Gynecol Scand 1978;78:33-43.

12. Peters DAV, Tang S. Sex-dependent biological changes following prenatal nicotine exposure in the rat. Pharmac Biochem Behav 1982;17:1077-1082.

13. Rowell PP, Clark MJ. The effect of chronic oral nicotine administration on fetal weight and placental amino acid accumulation in mice. Toxicol Appl Pharmacol 1982;66:30-38.

14. Wertelecki W, Hoff C, Zansky SZ. Maternal smoking: greater effect on males, fetal tobacco syndrome? Teratology 1987;35:317320.

15. Paulson R, Shanfeld J, Mullet P, Cola J, Paulson J. Prenatal smokeless tobacco effects on the rat fetus. J Craniofac Genet Dev Biol 1994;14:16-25.

16. Saad AY, Gartner LP, Hiatt JL. Teratogenic effects of nicotine on palate formation in mice. Biol Struct Morphog 1991;3:31-35.

17. Frommer J, Mergolies MR. Contribution of Meckel's cartilage to ossification of the mandible in mice. J Dent Res 1971;50:12601267.

18. Fuentes A. Structure foetale du maxillaire inferieur. Secteurs anterieurs et condyle. Rev Stomatol Chir Maxillofac 1991; 92:124-132.

Accepted March 10, 2003 